Tinjauan Pustaka

\title{
PERANAN TROMBOSIT DALAM PATOGENESIS MALARIA
}

\author{
Diana Natalia
}

\begin{abstract}
Abstrak
Malaria merupakan penyakit endemik di Indonesia dan mempengaruhi hampir seluruh komponen darah. Anemia dan trombositopenia merupakan komplikasi malaria terkait hematologi yang paling sering, dan mendapat banyak perhatian pada literatur ilmiah karena berhubungan dengan mortalitas. Penurunan jumlah trombosit berkaitan dengan berbagai penyebab diantaranya lisis dimediasi imun, sekuestrasi pada limpa, gangguan pada sumsum tulang dan fagositosis oleh makrofag. Infeksi malaria menyebabkan abnormalitas pada struktur dan fungsi trombosit. Kejadian trombositopenia dapat dijadikan petunjuk penting malaria akut.
\end{abstract}

Kata kunci: anemia, malaria, trombositopenia

\begin{abstract}
Malaria are endemic infection in Indonesia and are commonly associated with hematological abnormalities. Anemia and thrombocytopenia are the most common complication of malaria, and has been reported because its mortality. Thrombocytopenia is caused by immune lysis mechanism, spleen's sequestration, defect in bone marrow and macrophage phagocytosis. Malaria infection causes the abnormality in the structure and function of platelets. The presence of thrombocytopenia is important as an indicator of acute malaria.
\end{abstract}

Keywords: anemia, malaria, thrombocytopenia

Afiliasi Penulis : Departemen Parasitologi, Fakultas Kedokteran Universitas Tanjungpura Pontianak, Kalimantan Barat, Korespondensi : Diana Natalia, email : dnat_2005@yahoo.com, Telp \HP : 081382311690 


\section{PENDAHULUAN}

Malaria adalah penyakit infeksi parasit yang disebabkan oleh Plasmodium di dalam darah. ${ }^{1}$ Malaria merupakan penyakit endemik di lebih dari 100 negara di Afrika, Asia, Oceania dan Amerika Selatan dan Tengah serta di beberapa kepulauan Karibia. ${ }^{2}$ Malaria juga merupakan salah satu masalah kesehatan masyarakat di Indonesia. Pemerintah memandang masalah malaria masih sebagai ancaman terhadap status kesehatan masyarakat terutama pada rakyat miskin yang hidup di daerah terpencil. ${ }^{3}$ Malaria mempengaruhi angka kesakitan bayi, balita dan ibu melahirkan, serta menimbulkan kejadian luar biasa (KLB). Besarnya angka kasus baru malaria tahun 2009/2010 di seluruh Indonesia adalah 22,9 \%. Kalimantan Barat termasuk dalam 10 besar kasus baru malaria dengan nilai $53,1 \%{ }^{4}{ }^{4}$

Infeksi kronis Plasmodium falciparum dapat menyebabkan komplikasi malaria berat, seperti malaria serebral, malaria algid, anemia berat, gagal ginjal, edema paru hingga Acute Respiratory Distress Syndrome, hipoglikemia, syok, Disseminated Intravascular Coagulation, dan kelainan hati. ${ }^{2,5}$

Penelitian di Bangkok menunjukkan kadar trombosit secara signifikan lebih rendah pada kasus malaria berat dibanding malaria tanpa komplikasi. ${ }^{6}$ Sedangkan penelitian di Nigeria terhadap malaria pada anak menyebutkan bahwa derajat trombositopenia dapat menjadi alat yang berguna untuk menentukan derajat keparahan malaria dimana rerata jumlah trombosit menurun secara signifikan sesuai dengan peningkatan derajat parasitemia pada malaria. ${ }^{7} \mathrm{Di}$
Indonesia masih menilai kadar hemoglobin sebagai indikator malaria berat, padahal infeksi Plasmodium juga mempengaruhi kadar trombosit dalam darah tepi, dan berhubungan dengan patogenesis malaria berat.

\section{METODE}

Artikel ini ditulis berdasarkan hasil pene-lusuran dan review kepustakaan mengenai peran trombosit dalam patogenesis malaria.

\section{HASIL DAN PEMBAHASAN}

Malaria adalah penyakit infeksi parasit yang disebabkan oleh spesies Plasmodium yang menyerang dan berkembang biak dalam eritrosit dengan vektor nyamuk Anopheles betina, yang menularkan bentuk sporozoit malaria melalui gigitan nyamuk. Infeksinya dapat bersifat akut ataupun kronis, tergantung dari jenis spesies Plasmodium yang menginfeksi. ${ }^{1,3,8}$

\section{Epidemiologi Malaria}

Malaria ditemukan di daerahdaerah yang terletak pada posisi $64^{\circ}$ Lintang Utara sampai $32^{\circ}$ Lintang Selatan. Penyebaran malaria pada ketinggian 400 meter di bawah permukaan laut dan 2600 meter di atas permukaan laut. ${ }^{5}$ Malaria merupakan penyakit endemik di lebih dari 100 negara di Afrika, Asia, Oceania dan Amerika Selatan dan Tengah serta di beberapa kepulauan Karibia. $^{2}$

Data WHO menyebutkan tahun 2008 terdapat 544.470 kasus malaria positif di Indonesia, sedangkan pada tahun 2009 terdapat 1,1 juta kasus malaria klinis, dan pada tahun 2010 meningkat 
lagi menjadi 1,8 juta kasus malaria klinis dan telah mendapatkan pengobatan. ${ }^{9}$

Sebagian besar daerah di Indonesia masih merupakan daerah endemik infeksi malaria, Indonesia bagian timur seperti Papua, Maluku, Nusa Tenggara, Sulawesi, Kalimantan dan bahkan beberapa daerah di Sumatra seperti Lampung, Bengkulu, Riau. Di daerah Jawa dan Bali walaupun endemisitas sudah sangat rendah, masih sering dijumpai letupan kasus malaria, dan tentu saja hal ini disebabkan mudahnya transportasi untuk mobilisasi penduduk, sehingga sering menyebabkan timbulnya malaria impor. ${ }^{10}$

\section{Etiologi Malaria}

Parasit penyebab malaria adalah spesies Plasmodium. Plasmodium adalah parasit yang termasuk filum Protozoa, kelas sporozoa. ${ }^{11}$ Terdapat lima spesies Plasmodium pada manusia yaitu: Plasmodium vivax menimbulkan malaria vivax (malaria tertiana benigna). Plasmodium falciparum menimbulkan malaria falciparum (malaria tropika, malaria tersiana maligna). Plasmodium malariae menimbulkan malaria kuartana, dan Plasmodium ovale menimbulkan malaria ovale. ${ }^{6,8}$ Plasmodium knowlesi merupakan spesies parasit malaria yang ditemukan pada kera, yang menyerupai Plasmodium falciparum dan Plasmodium malariae, yang pada tahun 1965 di Malaysia dilaporkan spesies ini dapat menginfeksi manusia dan menyebabkan gejala klinis. ${ }^{6} \mathrm{Di}$ Indonesia, jenis ini telah ditemukan di daerah Kalimantan Sela$\tan$.

Plasmodium pada manusia menginfeksi sel darah merah dan mengalami pembiakan aseksual di jaringan hati dan eritrosit. Pembiakan seksual terjadi pada tubuh nyamuk yaitu Anopheles betina. ${ }^{1}$

\section{Patogenesis Malaria}

Patogenesis malaria berat sangat kompleks, melibatkan faktor parasit, faktor pejamu, dan faktor sosial lingkungan. Ketiga faktor tersebut saling terkait satu sama lain, dan menentukan manifestasi klinis malaria yang bervariasi mulai dari yang paling ringan (asimptomatik) hingga yang paling berat yakni malaria dengan komplikasi gagal organ. ${ }^{4}$

Perhatian utama dalam patogenesis malaria berat adalah sekuestrasi eritrosit berisi parasit stadium matang ke dalam mikrovaskular organ-organ vital. Faktor lain seperti induksi sitokin TNF-a dan sitokin-sitokin lainnya oleh toksin parasit malaria dan produksi nitrit oxide (NO) juga diduga mempunyai peranan penting dalam patogenesis malaria berat. ${ }^{1}$ Perkembangan malaria berat merupakan hasil dari kombinasi faktorfaktor spesifik parasit seperti adhesi dan sekuestrasi dalam pembuluh darah dan dilepaskannya molekul-molekul bioaktif bersamaan dengan respon peradangan pejamu. ${ }^{12}$ Interaksi sel dalam patogenesis malaria disajikan dalam gambar 1 .

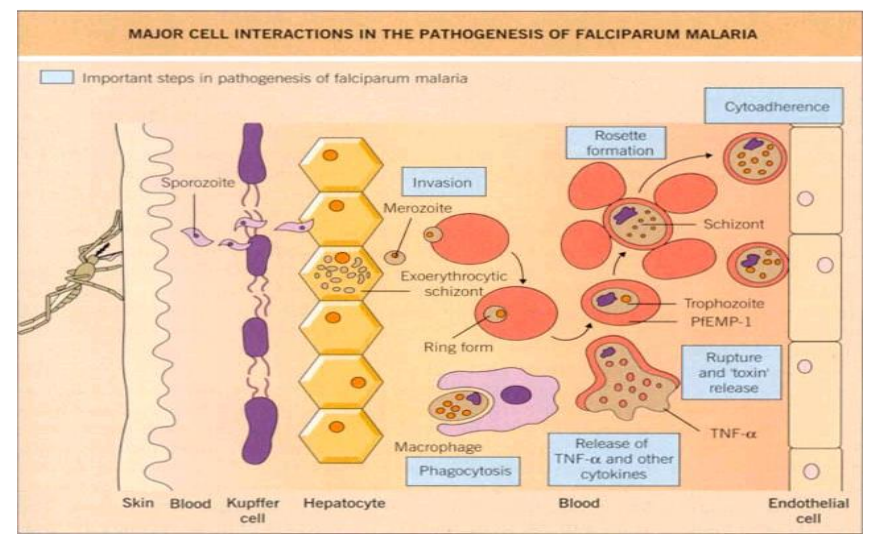

Gambar 1. Interaksi sel dalam patogenesis malaria $^{13}$ 


\section{Peran Trombosit dalam Patogenesis Malaria}

Parasit malaria berada dalam darah pada sebagian besar siklus hidupnya sehingga menginduksi perubahan dalam darah. Malaria mempengaruhi hampir seluruh komponen darah. Abnormalitas darah yang telah dilaporkan sehubungan dengan infeksi malaria antara lain anemia, trombositopenia, splenomegali, limfositosis ringan hingga berat serta (dalam kasus yang jarang) Disseminated Intravascular Coagulation (DIC). Anemia dan trombositopenia merupakan komplikasi malaria terkait hematologi yang paling sering, dan mendapat banyak perhatian pada literatur ilmiah karena berhubungan dengan mortalitas. ${ }^{14}$

Perubahan jumlah leukosit total tidak signifikan pada malaria. Gambaran leukosit pada penderita malaria beragam, tergantung dari berbagai faktor seperti lamanya infeksi (akut atau kronis), derajat parasitemia, keparahan penyakit, status imunitas pejamu dan infeksi campuran. ${ }^{5}$ Kadar leukosit total biasanya normal pada malaria akut, atau terjadi leukopenia pada malaria falciparum akut. Pada kasus anak-anak dan dewasa dengan malaria berat dan komplikasi, dapat terjadi leukositosis. ${ }^{15}$

Semua jenis parasit penyebab malaria pada manusia menginfeksi eritrosit. ${ }^{6}$ Eritrosit yang terinfeksi akan pecah saat melepaskan merozoit sehingga menyebabkan hemolisis. Kejadian ini terjadi berulang kali dan menyebabkan anemia hemolitik hipokromik mikrositik atau normokromik mikrositik. ${ }^{9}$

Meskipun malaria merupakan infeksi pada eritrosit, patofisiologi utama dalam perkembangan malaria berat adalah interaksi antara sel terinfeksi dan endotelium mikrovaskular. ${ }^{15}$ Aktivasi sel endotel vaksular dianggap sebagai suatu ciri infeksi malaria yang umum terjadi dan memainkan peranan penting dalam patogenesis malaria dengan meningkatkan sekuestrasi dari eritrosit terinfeksi parasit ke pembuluh darah perifer. Trombosit dan produk aktivasinya terlibat dalam sekuestrasi dari eritrosit terinfeksi pada endotel kapiler dan venula, yang merupakan kunci dari proses patologis malaria berat. ${ }^{15}$ Beberapa studi mengaitkan derajat trombositopenia dengan tingkat keparahan malaria. ${ }^{6}$

Terdapat beberapa mekanisme yang dipostulasikan sebagai penyebab terjadinya trombositopenia, diantaranya destruksi dimediasi imun, abnormalitas pada struktur trombosit yang diinvasi parasit, apoptosis platelet, DIC (Disseminated Intravascular Coagulation), sekuestrasi pada limpa (splenomegali), gangguan koagulasi, dan stress oksidatif. $4,16,17$

Plasmodium falciparum dapat memodifikasi permukaan eritrosit sehingga terdapat tonjolan-tonjolan, yang disebut knob, sehingga eritrosit terinfeksi parasit akan bersifat mudah melekat, terutama pada eritrosit sekitarnya yang tidak terinfeksi, trombosit dan endotel kapiler. ${ }^{4}$ Hal tersebut akan menyebabkan pembentukan roset dan gumpalan dalam pembuluh darah yang dapat memperlambat mikrosirkulasi. Akibatnya secara klinis dapat terjadi gangguan fungsi ginjal, otak dan syok. ${ }^{5}$

Terdapat beberapa reseptor yang dapat berikatan pada protein PfEMP (Plasmodium falciparum Erythrocyte Membrane Protein) yang terdapat pada knob ertitrosit terinfeksi parasit. Salah satunya adalah reseptor CD36 yang terdapat pada trombosit dan endotel pembuluh darah. Penggumpalan dari eri- 
trosit terinfeksi parasit, yang berhubungan dengan keparahan penyakit, terutama dimediasi oleh reseptor CD36 yang diekspresikan oleh trombosit. ${ }^{12}$ Penempelan dan agregasi trombosit dapat menyebabkan kegagalan perfusi organ dan hipoksia jaringan. ${ }^{16}$ Aktivasi platelet pada malaria falciparum diilustrasikan pada gambar 2 .

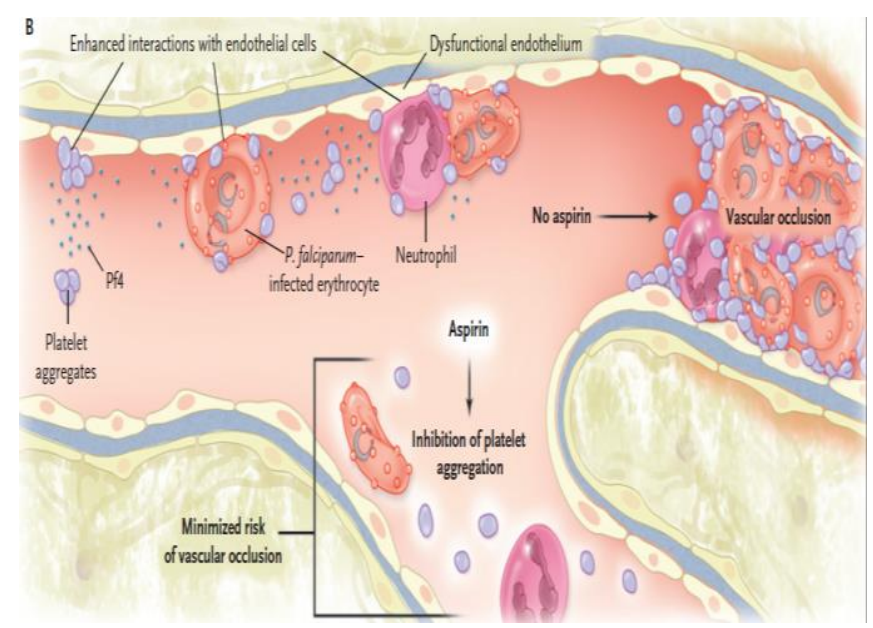

Gambar 2. Aktivasi platelet pada malaria falciparum $^{18}$

Limpa memainkan peranan penting dalam respon imun terhadap parasit malaria. Terdapat studi yang menyebutkan terjadi sekuestrasi trombosit dalam limpa selama infeksi akut. ${ }^{4}$ Limpa secara normal menyimpan sepertiga trombosit yang dihasilkan, tetapi pada keadaan splenomegali, sumber ini dapat meningkat hingga $80 \%$, dan mengurangi jumlah trombosit yang beredar pada sirkulasi. ${ }^{19}$

Pada malaria, IgG yang berhubungan dengan trombosit (plateletassociated lgG, PAlgG) meningkat dan berhubungan dengan trombositopenia. Peningkatan PAlgG juga dapat diartikan sebagai aktivasi platelet. Antibodi antiplatelet tersebut dapat mengaktivasi membran trombosit, menyebabkan pembuangan trombosit oleh sistem retikuloendotelial (RE), terutama pada limpa. ${ }^{15}$
Antibodi IgG yang ditemukan pada membran trombosit juga menyebabkan gangguan agregasi trombosit dan meningkatnya penghancuran trombosit oleh makrofag. ${ }^{19}$

Makrofag diduga berperan dalam destruksi trombosit, dimana peningkatan macrophage-colony stimulating factor (M-CSF) berhubungan dengan trombositopenia. Trombosit difagosit oleh makrofag teraktivasi pada hati dan limpa. Malaria berat berhubungan dengan kadar M-CSF plasma yang lebih tinggi dari normal. Kadar M-CSF plasma yang meningkat pada malaria, meningkatkan aktivitas makrofag dapat memediasi destruksi trombosit. ${ }^{17}$

Masa hidup trombosit pada infeksi malaria berkurang akibat dari ikatan antigen malaria pada trombosit yang diikuti fagositosis yang dimediasi antibodi, atau aktivasi trombosit in vivo. Masa hidup trombosit berkurang menjadi 2-3 hari (normalnya 7-10 hari). ${ }^{7}$

Infeksi malaria menginduksi pengeluaran radikal hydroxyl $(\mathrm{OH})$ dari hepar yang mana bertanggung jawab dalam induksi stress oksidatif dan apoptosis. Parasit malaria sendiri dapat mengeluarkan sejumlah besar $\mathrm{H}_{2} \mathrm{O}_{2}$ dan $\mathrm{O}_{2} .^{20}$ Stress oksidatif, melalui lipid peroxidation, menyebabkan kematian trombosit prematur, dan menimbulkan trombositopenia. ${ }^{15}$ Membran trombosit kurang tahan terhadap stress oksidatif, diperkirakan peningkatan stress oksidatif dapat meningkatkan lisis trombosit. ${ }^{20}$

Penempelan dan agregasi trombosit pada malaria berhubungan dengan peningkatan kadar faktor von Willebrand (vWF) dan defisiensi ADAMTS13. Pada saat terjadi jejas, endotel vaskular menghasilkan vWF, yang akan mengaktivasi sistem koagulasi dan mening- 
katkan penggunaan trombosit. Selain itu, vWF yang berada di sirkulasi menjadi hipereaktif, yang dikenal sebagai konformasi aktif dari domain vWF A1 yang dapat mengikat trombosit secara spontan. ADAMTS13 merupakan metalloprotease yang bertanggung jawab untuk proteolisis dari multimer ultralarge and prothromnogenic vWF (UL-vWF). Pada pasien malaria, terjadi penurunan aktivitas ADAMTS 13 yang mengakibatkan peredaran UL-VWF, yang selanjutnya akan berikatan dengan trombosit, dan mengakibatkan trombositopenia di perifer. $^{21}$

Eritrosit yang terinfeksi Plasmodium falciparum memiliki kemampuan untuk menstimulasi sel endotel secara langsung. Hemolisis eritrosit pada infeksi malaria menghasilkan faktor proagregasi seperti adenosine diphosphate (ADP), yang dapat menimbulkan respon aktivasi dan agregasi trombosit. ${ }^{15}$

Abnormalitas pada struktur dan fungsi trombosit digambarkan sebagai konsekuensi infeksi malaria. Sebagian besar pasien dengan malaria berat memiliki gambaran darah tepi trombositopenia, namun tranfusi konsentrat trombosit hanya diindikasikan pada pasien dengan perdarahan sistemik. ${ }^{20}$

Berkurangnya peredaran trombosit di sirkulasi pada malaria juga diasumsikan akibat mekanisme dimediasi antibodi. Terjadi peningkatan antibodi antiplatelet IgG pada penderita malaria (baik malaria falciparum maupun vivax) yang mengaktivasi membran trombosit, yang menyebabkan pembuangan trombosit oleh sistem retikuloendotelial, khususnya pada limpa. Dalam limpa, trombosit diduga difagosit oleh makrofag teraktivasi. ${ }^{15}$

\section{Penatalaksanaan}

Pemberian tranfusi trombosit pada penderita malaria tidak diperlukan karena kadar trombosit dapat meningkat seiring dengan pemberian terapi antimalaria. Penelitian di Kamerun terhadap perubahan hematologis yang terjadi setelah pengobatan menunjukkan peningkatan kadar trombosit yang signifikan setelah terapi kombinasi amodiakuin artesunat, dibandingkan sebelum terapi $(p<0,001) .^{22}$

\section{SIMPULAN}

Penurunan jumlah trombosit berkaitan dengan berbagai penyebab diantaranya lisis dimediasi imun, sekuestrasi pada limpa, gangguan pada sumsum tulang dan fagositosis oleh makrofag. Infeksi malaria menyebabkan abnormalitas pada struktur dan fungsi trombosit. Kejadian trombositopenia dapat dijadikan petunjuk penting malaria akut. Namun, pemberian tranfusi trombosit pada penderita malaria tidak diperlukan karena kadar trombosit dapat meningkat seiring dengan pemberian terapi antimalaria.

\section{DAFTAR RUJUKAN}

1. Harijanto., Malaria. Di dalam: Sudoyo. Buku Ajar Ilmu Penyakit Dalam. Ed ke-4. Jakarta: Interna Publisher; 2009.

2. Sandjaja, B. Protozoologi Kedokteran. Jakarta: Prestasi Pustaka; 2007.

3. Direktorat Jendral Pengendalian Penyakit dan Penyehatan Lingkungan. Pedoman Penatalaksanaan Kasus Malaria di Indonesia, Departemen Kesehatan Republik Indonesia; 2008.

4. Badan Penelitian dan Pengembangan Kesehatan Kementerian Kesehatan 
Republik Indonesia. Riset Kesehatan Dasar; 2010.

5. Sutanto I. Pribadi W. Parasit Malaria. Di dalam: Buku Ajar Parasitologi Kedokteran, Ed ke-4. Jakarta: Balai Penerbit FKUI; 2009

6. Leowattana, W, Tungpukdee N, Thar SK, Nakarisi S, Srivilairit $S$, Kano $S$, et al. Changes in Platelet Count in Uncomplicated and Severe Falciparum Malaria, Southeast Asian J Trop Med Public Health. 2010;41(5):1035-1041.

7. George I, Ewelike-Ezeani C. Haematological Changes in Children With Malaria Infection in Nigeria. JMMS. 2011;2(4):768-771.

8. Soedarto. Buku Ajar Parasitologi Kedokteran. Jakarta: Sagung Seto; 2011

9. Dinas Kesehatan Kalimantan Barat. Profil Kesehatan Kalimantan Barat 2010. Pontianak; 2010.

10. Harijanto P. Tatalaksana Malaria untuk Indonesia. Di dalam: Sekretaris Jendral Kemkes RI, Buletin Jendela Data dan Informasi Kesehatan. 2011;1(1):23-28.

11. Natadisastra D, Agoes R. Parasitologi Kedokteran: Ditinjau dari Organ Tubuh yang Diserang. Jakarta: EGC; 2009

12. World Health Organization (WHO). Guidelines for the Treatment of Malaria. $2^{\text {nd }}$ ed. Jeneva: WHO; 2010

13. Mackintosh C, Beeson J, Marsh K. Clinical Features and Pathogenesis of Severe Malaria. TRENDS in Parasitology. 2004;20(12):597-603.

14. Bashawri LAM, Mandil AA, Bahnassy AA, Ahmed AM. Malaria: Hematological aspect. Annals of Saudi Medicine. 2002;22:372-377.
15. Abdalla S, Pasvol G. Malaria : A Hematological Perspective. London: Imperial College Press; 2004.

16. de Mast $Q$, Groot E, Lenting PJ, de Groot $P G$, McCall M, Saurerwein RW et al. Thrombocytopenia and Release of Activated von Willebrand Factor during Early Plasmodium Falciparum Malaria. JID. 2007;196(15):622-628.

17. Bhandary N, Vikram GS, Shetty H. Thrombocytopenia in Malaria: A Clinical Study. Biomedical Research. 2011;22(4):489-491.

18. Greenbaum D, FitzGerald G. Platelets, Pyrexia, and Plasmodia. NEJM. 2009;361(5):526-528.

19. Price S, Wilson L. Patofisiologi: Konsep Klinis Proses-Proses Penyakit. Ed 6. Jakarta: EGC; 2006.

20. Araujo CF, Lacerda MV, Abdalla DS, Lima ES. The Role of Platelet and Plasma Markers of Antioxidant Status and Oxidative Stress in Thrombocytopenia Among Patients with Vivax Malaria. Mem Ist Oswaldo Cruz. 2008;103(6):517-521.

21. Mast Q. Hematological Alterations In Malaria. Oisterwijk: Boxpress BV; 2011.

22. Ngole SIU, Theresa N, Moses S, Thomas N, Manka NE, Titanji VPK. Haematological changes and recovery associated with treated and untreated Plasmodium falciparum infection in children in the Mount Cameroon Region. Journal of Clinical Medicine and Research. 2010; 2(9):143151. 